\title{
Entrepreneurship research: the French literature in perspective
}

\author{
Alex Fernando Borges ${ }^{1}$ \\ ALESSANDRO GOMES ENOQUE ${ }^{1}$

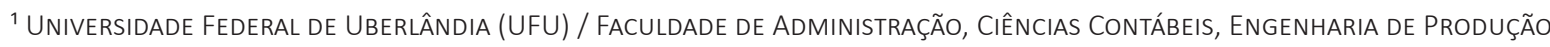 \\ E SERVIÇO SOCIAL, ITUIUTABA - MG, BRAZIL
}

\begin{abstract}
This article reviews entrepreneurship literature available in French. We reviewed articles published in the following French journals: Management International; Revue Française de Gestion; and Revue Internationale PME, considered relevant venues for entrepreneurship research (LASCH and YAMI, 2008), and based on inclusion and exclusion criteria established and detailed in the methodology. This allowed us to identify 166 entrepreneurship articles published in French from 2006 to 2019. To analyze and categorize these studies, we highlighted their presence in the aforementioned journals, the number of articles published per year, their main research topics, their methodological approach and techniques, and the most prominent researchers. The results show the predominance of specific topics such as public policies and support to entrepreneurship, intrapreneurship, entrepreneurial process and opportunities, women entrepreneurship, finance, entrepreneurial education, entrepreneurial behavior, entrepreneurial intention, entrepreneurs' motivations, and social entrepreneurship. Theoretical-empirical, qualitative studies are prevailing, but there is also room for theoretical papers on entrepreneurship. Finally, several researchers contribute to the field, investigating, writing, and publishing articles on entrepreneurship. In conclusion, we observed the formation of a plural, multifaceted francophone entrepreneurship field that presents theoretical-methodological possibilities and alternatives for the development of research on entrepreneurial phenomena.
\end{abstract}

Keywords: Entrepreneurship. Entrepreneur. Literature review. France. Canada.

\section{Pesquisa em empreendedorismo: a produção científica francófona em perspectiva}

\section{Resumo}

O objetivo do presente artigo consistiu em revisar a literatura em empreendedorismo publicada em língua francesa. Para tanto, estruturou-se uma revisão de escopo dos artigos listados em periódicos relevantes para o contexto francófono da produção científica em empreendedorismo (LASCH e YAMI, 2008): Management International; Revue Française de Gestion; e Revue Internationale PME, com base nos critérios de inclusão e exclusão detalhados e estabelecidos na metodologia do mapeamento. Isso possibilitou a categorização de 166 artigos que abordam a temática, publicados entre 2006 e 2019. Os textos foram analisados e categorizados em torno da distribuição dos artigos entre os periódicos, sua distribuição anual, principais temas de pesquisa, tipo de abordagem, escolhas metodológicas e principais autores do campo. Os resultados indicaram predominância de temáticas específicas na produção francófona, como: fomento ao empreendedorismo, intraempreendedorismo, processo empreendedor e oportunidades, empreendedorismo feminino, finanças, educação empreendedora, perfil e comportamento empreendedor, intenção empreendedora, motivações ao empreendedorismo e empreendedorismo social. Houve predominância de estudos teórico-empíricos, de natureza qualitativa, mas também com espaço significativo para ensaios teóricos sobre o tema. Verificou-se, ainda, a participação de um conjunto de autores centrais que produzem, pesquisam e disseminam resultados de suas investigações sobre empreendedorismo. Com isso, nota-se a constituição de um campo de pesquisas francófono em empreendedorismo plural e multifacetado, que apresenta possibilidades e alternativas teórico-metodológicas para a realização de estudos e investigações sobre o fenômeno empreendedor.

Palavras-chave: Empreendedorismo. Empreendedor. Revisão de literatura. França. Canadá.

\section{Investigación sobre emprendimiento: la producción científica francófona en perspectiva}

\section{Resumen}

El propósito de este artículo consistió en presentar una revisión de la literatura sobre emprendimiento publicada en francés. Para ello, se efectuó una revisión de los artículos enumerados en revistas relevantes para el contexto francófono de la producción científica sobre emprendimiento (LASH y YAMI, 2008): Management International; Revue Française de Gestion; y Revue Internationale PME, con base en los criterios de inclusión y exclusión detallados y establecidos en la metodología del mapeo. Esto permitió la categorización de 166 artículos que abordan el tema, publicados entre 2006 y 2019. Los textos se analizaron y categorizaron en torno a la distribución de artículos entre las revistas, su distribución anual, principales temas de investigación, tipo de abordaje, opciones metodológicas y principales autores del campo. Las evidencias muestran el predominio de temas de investigación específicos como: políticas públicas y apoyo al emprendimiento, intraemprendimiento, proceso emprendedor y oportunidades, emprendimiento femenino, finanzas, educación emprendedora, perfil y comportamiento emprendedor, intención emprendedora, motivaciones al emprendimiento y emprendimiento social. Predominaron los estudios teórico-empíricos y cualitativos, pero también con espacio significativo para ensayos teóricos sobre el tema. Asimismo, se verificó la formación de un campo de investigaciones sobre emprendimiento francófono plural y multifacético, que presenta posibilidades y alternativas teóricas y metodológicas para la realización de estudios e investigaciones sobre el fenómeno emprendedor.

Palabras clave: Emprendimiento. Emprendedor. Revisión de la literatura. Francia. Canadá. 


\section{INTRODUCTION}

Currently, there are several initiatives to delimit the scope and range of entrepreneurship research (LOPES and LIMA, 2019; SHEPHERD, WENNBERG, SUDDABY et al., 2019). The field has a multidisciplinary character, being influenced by different disciplines (TURCAN and FRASER, 2018), theoretical and methodological approaches (MCDONALD, GAN, FRASER et al., 2015; OLIVEIRA JUNIOR, GATTAZ, BERNADES et al., 2018; VALE, 2014) and various ontological and epistemological orientations (ALVAREZ and BARNEY, 2010; HJORTH, 2015). In this scenario, there is room for studies that aim to map the scientific production related to entrepreneurship, problematizing the specificities of the literature on the subject. Previous reviews focused on topics such as: central research themes (OLIVEIRA JUNIOR, GATTAZ, BERNADES et al., 2018), main research methods (MCDONALD, GAN, FRASER et al., 2015), main researchers in the field (TEIXEIRA, 2011), citations and co-citations analysis (MEYER, LIBAERS, THIJS et al., 2014), and the evolution, trends and agendas for future research (CLARK and HARRISON, 2019; FAYOLLE, 2014; SHEPHERD, WENNBERG, SUDDABY et al., 2019). These elements reflect the idiosyncrasies of entrepreneurship literature, highlight its relevance and dynamics, and reveal its scientific nature and the main challenges in the field (WIKLUND, WRIGHT and ZAHRA, 2019).

It is worth mentioning that entrepreneurship literature has also been reviewed from the point of view of the formation and structuration of the field in different countries, emphasizing the particularities of this scientific production in a regional perspective. A relevant source of production and dissemination of knowledge on entrepreneurship is observed in French-speaking countries, such as France and Canada. Indeed, France is commonly characterized as the origin site of the term "entrepreneur", which dates back to the 16th century (KIZABA, 2006; MARCHESNAY, 2011). However, from an academic point of view, the theme is relatively recently explored in this context, and the first publications in the management area emerged between the end of the 1980s and the beginning of the 1990s. The main scientific associations on the subject - Association Internationale de Recherche en Entrepreneuriat et PME (AIREPME) and Academie de l'Entrepreneuriat (AE) - date, respectively, from 1996 and 1998. The first specialized journal - Revue Internationale P. M. E- had its initial edition published in 1988. These events reveal the existence of a relatively emerging field of studies that is still in formation and in a constant restructuring (FAYOLLE, 2011; MARCHESNAY, 2008).

The Francophone literature on entrepreneurship is often considered as a secondary source of knowledge, shadowed by the mainstream of the field (FAYOLLE, 2011; MARCHESNAY, 2008). Such scenario may be explained by the barriers and limitations imposed by the language and due to the prevalence of studies and scientific production published in English, with greater international diffusion and legitimacy in the field. Nevertheless, Marchesnay (2008) argues that there is a search, in the French-speaking context, for the establishment of an original vision of entrepreneurship, based on the elaboration of alternative theoretical and methodological approaches to the analysis of research problems associated with the manifestation of this phenomenon. This includes, for example, a concentration on qualitative, exploratory investigations, a more subjective research focus, influenced by interpretivism, constructionism, constructivism, and structurationism approaches, an orientation for the exploration of different types of organizations and varied research methods and techniques (JULIEN and RAYMOND, 2008; KIZABA, 2006; LASCH and YAMI, 2008).

Thus, it becomes relevant to put the Francophone literature on entrepreneurship into perspective, identifying its possible patterns, trends and gaps. In this scenario, the question made by Gartner (1990) - what are we talking about when we talk about entrepreneurship? - can also be applied to the context of Francophone entrepreneurship research, opening space for the question that guides this paper: what are the particularities of the entrepreneurship literature published in the French language? To answer this question, the purpose of the paper is to review the entrepreneurship literature published in the French language, using scope literature review approach. To this end, a survey of articles published in the journals Management International (MI), Revue Française de Gestion (RFG) and Revue Internationale P. M. E. (RIPME) was carried out. These journals were selected based on detailed inclusion and exclusion criteria established in the methodological section of the present scope review and they are considered as relevant means of dissemination for the French-speaking scientific production on entrepreneurial phenomena, especially because they give an editorial opening to the theme as in the cases of the generalist MI and RFG journals - and due to the relation with scientific associations focused on the subject - as RIPME (FAYOLLE, 2011, 2017; LASCH and YAMI, 2008; MARCHESNAY, 2008, 2011). This way, the scope review 
technique enabled the identification and categorization of 166 papers related to entrepreneurship, published between 2006 and 2019. Based on this, the mapping was structured and guided to enable the analysis of essential aspects linked to this production. It sought to list the particularities of the Francophone publication, highlighting its possible contributions to entrepreneurship research in Brazil.

\section{Entrepreneurship: research and scientific production}

Entrepreneurship involves a set of actions and situations related with entrepreneurs' practice and the understating of how its dynamics and processes influences their businesses. Gartner (1990) points out that talking about entrepreneurship encompasses a wide set of beliefs and assumptions about what constitutes this phenomenon, its conceptual framework and its possibilities of manifestation.

In addition, the subject may be defined from different perspectives. It derives from the relationship between the understanding of entrepreneurship as a phenomenon and the role played by entrepreneurs as agents (GARTNER, 2012). Based on this notion, each school of thought in the field presents a more or less central definition for entrepreneurial phenomena. From a behavioral perspective, entrepreneurship has been considered as the object of decisions and actions of an entrepreneur, an individual with a particular behavior and with certain personality traits that differentiate him from other agents in the economy and in society (FILION, 1999). From an economic perspective, the entrepreneurial phenomenon can be understood from the innovation point of view, which includes the analysis of actions of individuals who act independently or within established organizations, introducing new products, services, processes and technologies in the market (CARLSSON, BRAUNERHJELM, MCKELVEY et al., 2013). From a process perspective, entrepreneurship is defined based on the presence of lucrative opportunities and the existence of individuals willing to identify and explore them. In other words, this perspective entails the visualization of entrepreneurship as the result of an entrepreneurial process, properly organized in terms of the creation and/or identification of business opportunities (SHANE and VENKATARAMAN, 2000). Finally, from an organizational perspective, entrepreneurship is seen as organization creation, a structured movement based on processes of emergency, innovation and transformation of organizations (GARTNER and BRUSH, 2016).

Once there is a profusion of definitions available for terms such as entrepreneurship and the entrepreneur, it is necessary to consider the differences between some conceptual approaches. Entrepreneurship literature in the U.S., often considered a reference in the field, is responsible for the generation and dissemination of concepts at the international level, being the origin of behavioral and processual perspectives (MEYER, LIBAERS, THIJS et al., 2014). In turn, the economic perspective was originally developed within the German and Austrian entrepreneurial schools, linking the phenomenon to the notion of innovation and to the idea of economic development (SCHMUDE, WELTER and HEUMANN, 2008). The organizational perspective has its roots associated with the European context, with elaborations and theoretical foundations observed in the works of authors from the United Kingdom, Sweden, Norway, Finland, Denmark and the Netherlands (GARTNER, 2012). These are, then, countries with a certain tradition in entrepreneurship research. This fact has an impact on the development and consolidation of particular thought schools that delimit the nature and logic of the scientific production on entrepreneurship and demarcate the contribution of literature originated from these countries to the broader research scope about this phenomenon.

From the point of view of scientometrics and bibliometrics, it is observed that entrepreneurship studies began to take on academic bodies from the 1980s (MEYER, LIBAERS, THIJS et al., 2014). This literature gained momentum with its acceptance in relevant journals in the Business and Management fields (MACMILLAN, 1993). Howeber, entrepreneurship papers remained, in the early years, with a small participation in comparison to the total production about the entrepreneurial phenomenon (HARRISON and LEITCH, 1996). In this context, the first efforts to review scientific production on entrepreneurship emerged between the end of the 1980s and the beginning of the 1990s (BUSENITZ, WEST, SHEPHERD et al., 2003). The same can be said about Francophone production, which emerged in the mid-1980s and evolved in the 1990s (FAYOLLE, 2011; MARCHESNAY, 2011).

Busenitz, West, Shepherd et al. (2003), through an analysis of 97 articles published between 1985 and 1999 in journals in the Management field, verified the emergence of entrepreneurship as a particular domain of research, through the growth of empirical studies about the phenomenon and the knowledge basis of the field. The authors conclude that, in order to achieve legitimacy as a proper and independent field, researchers must seek to identify the boundaries of what is entrepreneurship and develop a solid theoretical basis, in order to expand it beyond its emergency stage. 
Busenitz, Plummer, Klotz et al. (2014) compares the evolution of entrepreneurship research in the period between 2000 and 2009 with their previous study of the scientific production observed between 1985 and 1999 (BUSENITZ, WEST, SHEPHERD et al., 2003). They identified 216 entrepreneurship articles in Management journals and 644 papers published in entrepreneurship specialized journals - Journal of Business Venturing and Entrepreneurship Theory and Practice. The authors noted that research in the area substantially grew over the 1980s, 1990s and 2000s, showing increasing interest in topics such as business opportunities and environmental and contextual aspects of entrepreneurship. In addition, the authors point out that the field shows an increase not only in the volume of published articles, but also in its impact observed by the increase in citations to this set of papers, a fact that indicates the growth in the legitimacy of entrepreneurship as a research field.

Ferreira, Pinto e Miranda (2015) analyzed the structure of entrepreneurship research, comprising 30 years of publications on the subject (1981-2010) in relevant international journals. Their review offered an overview of the most productive authors in the field and their nationalities, the main literature works, the volume of citations, co-citations and main researched topics. They identified a growth pattern in the field's scientific production, with the exploration of topics as: entrepreneurial process; opportunities; creation of value/innovation and performance; psychological, cognitive and behavioral characteristics of entrepreneurs; and theories, methods and techniques of research. The authors conclude that the area is based on evidence of empirical phenomena, being, to a certain extent, "non-theoretical". Thus, there is a need for studies that delimit the field of entrepreneurship research, with greater rigor and methodological sophistication.

At the same time, it is necessary to detail the way in which entrepreneurship literature has been worked in regional contexts. The studies of Kizaba (2006), Blackburn and Smallbone (2008), Lasch and Yami (2008), Schmude, Welter and Heumann (2008), Ferreira, Santos, Reis et al. (2010), Nassif, Silva, Ono et al. (2010), and Oliveira Junior, Gattaz, Bernades et al. (2018), helped to shed light on these different realities, problematizing research themes, theoretical-methodological approaches and concentration of authorship and research institutions, as well as the processes of legitimization and institutionalization of the field in different countries.

The study by Blackburn and Smallbone (2008), structured with the purpose of mapping the development of entrepreneurship research in the United Kingdom, identified some of the characteristics that distinguish the production in that country. The paper points to a fast growth in the number of researchers contributing to the field in a period of 30 years, as well as its increasing legitimacy and institutionalization. Research in the UK is marked by a rich diversity of themes and approaches, covering topics such as the formation of public policies for entrepreneurship, growth, development and survival of small businesses, the entrepreneur, the formation of networks and external relationships, technology, globalization, innovation and intellectual property, and conducting comparative studies with other international contexts. Thus, issues such as a strong empirical tradition, a wide methodological diversity, the emphasis on small businesses and the setting up of a pre-paradigmatic and intermediate stage of theoretical development in the field can be highlighted in the British research field on entrepreneurship, comprised between a generalist theory and a strong orientation towards empirical findings.

In turn, Schmude, Welter and Heumann (2008) reviewed entrepreneurship literature published in Germany, seeking to identify how German research is distinguished and differentiated from the mainstream (especially the American). The review highlighted the emergence of a specific field in the 1990s, due to the emergence of entrepreneurship chairs in German universities and the first annual conference on the subject. The authors found that the field is strongly influenced by its historical roots, involving a tendency to consider contextual specificities and multidisciplinarity, because of the interaction with the Austrian School of innovation (including Schumpeter), and with Max Weber's conceptions of entrepreneur and the broader social context. Therefore, German research is marked by the predominance of studies about the context and the relationship between entrepreneurship and the macroenvironment (including the role of this phenomenon in terms of regional, sectoral and economic development) influenced by the Schumpeterian school. There is also an important concern with issues such as the role of universities in the entrepreneurial context and regarding entrepreneurial education, venture capital, public policies, entrepreneurial behavior and the psychological characteristics of entrepreneurs (including a research stream on differences between West and East German entrepreneurs), and female entrepreneurship. 
Alongside this European context, Brazilian research and scientific production must also be put into perspective. Nassif, Silva, Ono et al. (2010) present a retrospective balance of the Brazilian entrepreneurship literature, considering the 127 communications from the ANPAD Conference (EnANPAD), between 2003 and 2008, and the 163 texts of the Small Business and Entrepreneurship Conference (EGEPE), from 2000 to 2008. Within the 290 analyzed papers, the authors observed a concentration around topics that relate the entrepreneur's behavior, attitude, profile and skills, from a theoretical-empirical perspective. The review by Ferreira, Santos, Reis et al. (2010) sought to examine the state of the art of entrepreneurship research in Brazil, through the analysis of 156 papers published in the EnANPADs between 1997 and 2008. The results indicate that the communications explored a wide spectrum of topics, with focus on contextual, individual and processual factors. There was an increase in the volume of contributions in the analyzed period, marked by empirical investigations and case studies.

More recently, Oliveira Junior, Gattaz, Bernades et al. (2018) carried out a systematic review of entrepreneurship papers published in the six main Brazilian management journals, from 2000 to 2014. Among the most studied themes by the researchers, there was an emphasis on investigations about the entrepreneur, social entrepreneurship, networks and social capital, entrepreneurial orientation, female entrepreneurship, and entrepreneurial education. Within the scope of methodological approaches, there was a prevalence of qualitative studies, based on personal interviews and case studies. The authors concluded that the field has a relatively small volume of scientific production in the main Brazilian journals. Such a fact would require more rigorous empirical studies, the expansion of the existing theoretical basis and the creation of research lines on entrepreneurship in national higher education institutions.

Finally, it is important to highlight the singularities of the Francophone entrepreneurship literature. Kizaba (2006) presented an evaluation of scientific reviews and shed light on ten years of French-speaking entrepreneurship research, describing the characteristics and trends from published papers between 1995 and 2005 in the journals Revue Internationale PME, Revue de I'Entrepreneuriat, Revue des Sciences de Gestion and Gestion 2000. The review identified a total of 125 articles, highlighting themes associated with the entrepreneur's profile and behavior, the creation of organizations and the entrepreneurial process, innovation, cooperation and internationalization strategies, the management of small business, sources of financing and fostering entrepreneurship, entrepreneurial learning and education, and the role of the State in the promotion of entrepreneurship. Kizaba (2006) concluded that it was possible to observe, in the analyzed period, the constitution of a particular field of studies, influenced by historical processes of incubation, emergence, growth, institutionalization and objectification, with a research reorientation from a field strongly influenced by international academic sources to the delimitation of a "French touch" to study entrepreneurship. This included the transition of research focus from the individual to the process, from positivism to constructivism, from quantitative to qualitative studies. In addition, there was a deep concern, from an empirical point of view, with small businesses and with the definition of scientific positions through the valorization of epistemological discussions.

Lasch and Yami (2008), in turn, presented an overview of the specificities of Francophone entrepreneurship research. According to the authors, the emergence of scientific production on the subject dates from the period between the end of the 1980s and the beginning of the 1990s, with a significant growth of this literature observed after 1995 and the consequent increase in the recognition and legitimacy of the field in France.

The mapping carried out by Lasch and Yami (2008) identified a total of 253 papers, published between 1996 and 2005 in two journals from Canada and France, respectively - Revue Internationale PME (RIPME) and Revue de l'Entrepreneuriat (RENT) - and in two international academic conferences from the French-speaking community - Conference Internationale Francophone en Entrepreneuriat et PME (CIFEPME) and Académie de l'Entrepreneuriat (AE). This literature review revealed a predominance of studies applied to the reality of small business, with an emphasis on qualitative methods, and an appreciation of theoretical and conceptual contributions. In addition, this mapping identified a research concentration on topics such as the entrepreneurial process (discussing aspects such as the recognition of opportunities, the resources acquisition and business strategies, among others) and the entrepreneur's background (involving issues such as the origin, personality, behavior and the decision-making process), comprising $40 \%$ of the total published articles. However, topics associated with entrepreneurship from an organizational point of view (intrapreneurship, innovation, etc.) and from an environmental point of view (context, public policies, etc.) showed up as emerging topics of investigation. This set of evidence points to a distinction from the empirical positivism that is typical on entrepreneurship research conducted in the United States (LASCH and YAMI, 2008). 
However, it is necessary to present some considerations regarding the particularities and contributions of the Francophone entrepreneurship literature. It seems to be a consensus among authors concerned with the configuration of the French-speaking field that the area is emerging, complex and multifaceted, being marginalized from the international point of view due to cultural, language barriers, and its embryonic stage of legitimation and institutionalization (FAYOLLE, 2011, 2017; LASCH and YAMI, 2008; MARCHESNAY, 2008, 2011). The North American process school and the European organizational school have conceptually influenced these studies. Such influences reverberated in the configuration of papers that valued elements such as the entrepreneurial process and entrepreneurial opportunities, intrapreneurship and innovation, and the particularities of business creation events and the idiosyncratic elements of small business management (FAYOLLE, 2011; MARCHESNAY, 2008). From the conceptual point of view, there are difficulties in establishing definitions about entrepreneurship and delimiting its frontiers, its scope and its limits in a Francophone perspective. France is marked culturally and historically by several social conflicts, involving ideological disputes influenced by the class struggle and that question the entrepreneur's social status, and by an organizational culture based on managerialism and bureaucracy (MARCHESNAY, 2008).

Thus, although there is no conceptual delimitation entirely different from those observed in other schools of thought, Fayolle (2011) points out that the Francophone literature tends to delimit entrepreneurship as an action-based phenomenon, moving away to some extent from the North American behavioral and the Germanic economic perspectives, and differing from North American processual concepts in the epistemological and methodological frameworks. In this sense, there is an emphasis on interpretive, constructionist, constructivist and structuralist schools, as well as a focus on conducting qualitative investigations and in-depth case studies (KIZABA, 2006; MARCHESNAY, 2011). In this sense, despite the pertinence of the aforementioned remarks, there are evidences that point out specificities of the Francophone literature in a theoretical and methodological perspective, which suggest the demarcation of a "French touch" to research entrepreneurship (FAYOLLE, 2017; MARCHESNAY, 2008; LASCH and YAMI, 2008).

Therefore, it is shown that the evolution and the particularities of the field make it possible to develop revision studies that seek to map the available literature about entrepreneurship in French language, pointing to the scope, breadth, range and depth of studies that address this research subject. Hence, it means to answer the still current question presented in the seminal work by Gartner (1990) - what are we talking about when we talk about entrepreneurship? - although under a French perspective or touch (FAYOLLE, 2011; FAYOLLE, 2017; JULIEN and RAYMOND, 2008; LASCH and YAMI, 2008; MARCHESNAY, 2008; MARCHESNAY, 2011). This paper do so by reviewing fifteen years of Francophone literature on entrepreneurship, adding new evidence to those highlighted in the studies carried out by Bizaka (2006) and by Lasch and Yami (2008). Furthermore, this paper seeks to introduce this debate to the field of entrepreneurship studies in Brazil, in order to suggest possibilities for new research and the exploration of alternative approaches related to entrepreneurial phenomena.

\section{METHOD}

In this section, we present the methodological procedures that guided our review. Accordingly with our purpose, we sought to map the available Francophone literature on entrepreneurship using the method of scope literature review. Arksey and O'Malley (2005) define that the scope review aims to map the central elements of a research field, examining the extent, scope and nature of publications on a given topic. According to Rumrill, Fitzgerald and Merchant (2010), this procedure offers a guidance for reviewing the available literature on a specific research topic. Thus, it establishes a synthesis that contributes to the understanding of the particularities of the scientific field in question, enabling the identification of patterns, trends and gaps in the area, creating an overview of the study agenda and guiding future investigations on a given subject. 
Indeed, since there are several methodologies available for carrying out literature reviews, it becomes necessary to differentiate the scope review from other techniques. Rumrill, Fitzgerald e Merchant (2010) argues that the scope review emerges is an alternative to traditional review methods. On the one hand, bibliometry aims at quantifying and statistically analyzing theoretical and methodological topics, relationships on authoring and co-authoring and citation and co-citation, presenting a broad view of the literature, but in a relatively superficial way. On the other hand, systematic reviews raise quantitative data on the empirical evidence related to a given research topic and involve the use of specific statistical techniques to summarize, standardize and better translate the research results into aggregated data with some depth. In this sense, the scope review would be a kind of middle ground between the two aforementioned techniques, differentiating itself by densely apprehending the breadth of an emerging research topic through a rigorous and transparent methodology, although it is limited because it does not contemplate the synthesis of empirical evidence. This fact places the scope literature review as a more qualitative review and as a preliminary step to conducting systematic reviews on a given research topic (ARKSEY and O'MALLEY, 2005).

Scope reviews follow a pre-established path, using a script for its operationalization (ZUPIC and CATER, 2015). According to Arksey and O'Malley (2005) and Levac, Colquhuon and O'Brien (2010), the scope literature review comprises steps such as: a) the definition of the research question; b) the identification of relevant studies in the field based on refinements defined by the researchers, delimiting them according to the subject, the publication source, the time frame, the descriptors and keywords, among other criteria; c) mapping, involving the classification and categorization of the covered topics, the theoretical, empirical, and methodological nature of the studies and issues like authorship, among others; and d) the discussion and synthesis of results and/or comparison with other reviews. Thus, when adopting this technique, it would be possible to identify the patterns of the research field, providing relevant reflections for the development of future studies.

In this paper, the methodological operationalization of the scope review involved the following structure, inspired by the framework presented above. First, we defined our research problem (what are the particularities of the entrepreneurship literature published in the French language?). Then, we mapped entrepreneurship papers published in French (subject delimitation) between 2006 and 2019. We defined this time frame in order to enable an evaluation of the field in the aforementioned period, which is immediately subsequent to the time frame of Kizaba's (2006) and Lasch and Yami's (2008) reviews.

As a consequence, we mapped the Francophone literature in order to identify relevant articles for our scope review. Initially, we established some criteria for the selection of journals and articles to be mapped, namely: a) inclusion criteria - journal with editions and numbers on a regular frequency over the past 15 years; presence of full papers published in the French language; presence of papers with themes specifically associated with the entrepreneurship field; journals with open access and/or available at the survey time; b) exclusion criteria - journal with editions and numbers in irregular frequency and/or that did not comprehend the entire time frame indicated for the survey; journals with restricted access; journals from France and Canada with articles only published in English; bibliographical review papers, invited articles, editorial notes and similar; journals and articles which central focus does not correspond to the research question (papers related to specific topics, such as the management of small businesses and family firms, innovation, among others).

Based on these inclusion and exclusion criteria, articles published in the following journals were selected: a) Management International (MI), a generalist management journal published by HEC Montreal, the first business school in Canada; b) Revue Française de Gestion (RFG), a generalist management journal created in 1975 by the Fondation Nationale pour I'Enseignement de la Gestion des Entreprises (FNEGE) and published by Lavoisier, being classified as the main French journal in the Management field by the Comité National de la Recherche Scientifique (CNRS) and third highest h5 index among the French-speaking journals of all areas according to Google Scholar; and c) Revue Internationale PME (RIPME), an entrepreneurship and small business management journal created in 1988 and published by Editions Management et Societé (EMS), currently maintained through a partnership with AIREPME and the Institut de Recherche sur les PME from the Université du Québec au Trois-Rivières - Canada. It should be noted that these journals are considered as relevant means of the dissemination of Francophone entrepreneurship papers (LASCH and YAMI, 2008; FAYOLLE, 2017), mainly because they give an editorial opening to the subject - in the cases of $M I$ and $R F G$ - and for being related to the scientific association focused on the theme - the case of RIPME (FAYOLLE, 2011, 2017; LASCH and YAMI, 2008; MARCHESNAY, 2008, 2011). 
It must be highlighted that some generalist and specialized French-speaking journals were excluded from the survey due to the established criteria, such as Gestion 2000, Revue des Sciences de Gestion, Management Avenir, Marché et Organization (restricted access) and Revue de l'Entrepreneuriat (started after 2001). The aggregated data about the selected journals for the scope review are presented in Box 1 :

Box 1

Aggregated data about the selected journals for the scope review.

\begin{tabular}{|c|c|c|c|c|c|}
\hline Journal & Country & Indexers & $\begin{array}{c}\text { Impact Factor } \\
\text { (SJR) }\end{array}$ & $\begin{array}{c}\text { h5 Index } \\
\text { Google Scholar }\end{array}$ & $\begin{array}{c}\text { Ranking } \\
\text { CNRS/2019 }\end{array}$ \\
\hline $\begin{array}{c}\text { Management } \\
\text { International }\end{array}$ & Canada & Érudit & None & 10 & Category 2 \\
\hline $\begin{array}{c}\text { Revue Française } \\
\text { de Gestion }\end{array}$ & France & $\begin{array}{c}\text { Cairn, Ebsco, } \\
\text { Proquest, Scopus }\end{array}$ & 0,212 & 14 & Category 1 \\
\hline $\begin{array}{c}\text { Revue Internationale } \\
\text { PME }\end{array}$ & Canada & Érudit & None & 6 & Category 3 \\
\hline
\end{tabular}

Source: Elaborated by the authors.

Then, we identified and categorized the articles that were part of this. We analyzed and organized the papers through their descriptors, including elements such as their titles, abstracts, keywords and the content itself, which allowed an initial classification of these papers. After this stage, the literature was categorized taking into account the following topics: distribution of articles among the analyzed journals; annual distribution of published papers; main research topics; approach type of the articles (theoretical essays, theoretical-empirical articles, literature reviews); methodological choices; and main authors of the field. Hence, it was possible to map and contextualize the Francophone entrepreneurship literature, pointing out possible patterns, trends and gaps in this production, thus achieving the proposed objectives in this paper. Finally, it should be noted that the method for the articles classification was inspired by contributions from the literature reviews developed by Blackburn and Smallbone (2008), Julien and Raymond, (2008), Kizaba (2006), Lasch and Yami (2008), Marchesnay (2008), Oliveira Junior, Gattaz, Bernades et al. (2018), and Schmude, Welter and Heumann (2008).

\section{The Francophone literature on entrepreneurship}

As demonstrated earlir, the entrepreneurship literature has distinctive particularities and characteristics, with multiple concepts, approaches, theoretical frameworks and research methods. The analysis of this literature makes it possible to verify the existence of some specificities that are circumscribed to the source of the publication and/or the research carried out about the subject. In such scenario, different authors made efforts to review the literature to understand and explain the nature and logic of entrepreneurship studies in their different countries. Based on these initiatives, we sought to employ the scope review method within the Francophone entrepreneurship literature, considering the period from 2006 to 2019. We identified 166 published articles, according to the following distribution (Table 1): 
Table 1

Distribution of the Francophone entrepreneurship literature by journal

\begin{tabular}{lccc}
\hline \multicolumn{1}{c}{ Journal } & Nationality & Total of articles & $\%$ \\
\hline Management International (MI) & Canada & 42 & 25,30 \\
Revue Française de Gestion (RFG) & France & 60 & 36,14 \\
Revue Internationale PME (RIPME) & Canada & 64 & 38,56 \\
Total & & 166 & 100,00 \\
\hline
\end{tabular}

Source: Research data.

First, it is worth mentioning the presence of these works in generalist journals, as Management International (Canada) and Revue Française de Gestion (France). This finding reveals the editorial opening of these journals for the publication of entrepreneurship papers, a fact not always observed in journals considered as representatives of the academic mainstream in management/business published in other countries, as is the case of the United States, for example (MEYER, LIBAERS, THIJS et al., 2014). Despite being a generalist, the Revue Française de Gestion, one of the main scientific journals published in France, presented almost the same level of publication as a specialized journal on entrepreneurship and small business management (Revue Internationale PME). For comparison purposes, RFG average number of publications, in the in the analyzed period, was four articles per year. In the review carried out by Kizaba (2006), RFG average number of papers was approximately one per year in the between 1995 and 2005. This illustrates the importance of this production volume and the relevance given to such theme in the French-speaking context, and reinforces the identification of this editorial space for the publication of articles on entrepreneurship.

Another aspect that deserves consideration refers to the annual distribution of entrepreneurship papers published in Francophone journals (Table 2):

Table 2

Annual Distribution of Francophone entrepreneurship papers

\begin{tabular}{ccccc}
\hline Year & Management Intl. & Revue Française de Gestion & Revue Intl. PME & Total \\
\hline 2006 & 1 & 4 & 1 & 6 \\
2007 & 1 & 0 & 3 & 4 \\
2008 & 1 & 11 & 6 & 18 \\
2009 & 4 & 8 & 5 & 17 \\
2010 & 0 & 8 & 4 & 12 \\
2011 & 0 & 1 & 9 & 10 \\
2012 & 1 & 7 & 4 & 12 \\
2013 & 9 & 7 & 2 & 18 \\
2014 & 4 & 1 & 7 & 12 \\
2015 & 1 & 0 & 2 & 3 \\
2016 & 8 & 3 & 0 & 11 \\
2017 & 2 & 1 & 8 & 11 \\
2018 & 3 & 1 & 6 & 10 \\
2019 & 7 & 8 & 7 & 22 \\
Total & 42 & 60 & 64 & 166 \\
\hline
\end{tabular}

Source: Research data. 
Mapping the annual distribution of Francophone entrepreneurship papers reveal some particular aspects. On the one hand, it is possible to see an increase in the interest about the subject, especially between 2008 and 2014. This increase can be partially explained by the influence of calls for papers, particularly observed in generalist journals, a strategy that encourages entrepreneurship researchers to present their research results or their theoretical propositions in the analyzed journals. There were eight calls for papers on entrepreneurship and related subthemes, involving issues such as intrapreneurship, sectorial entrepreneurship, entrepreneurial behavior, female entrepreneurship, social capital, crowdfunding, entrepreneurship fostering, and entrepreneurial education. In this sense, there is an important interest of these journals and their editorial teams in opening space and promoting the dissemination of papers about entrepreneurship, providing opportunities for further studies and research on the subject. However, with the decrease in the number of calls for papers on the topic, there was a relative decrease in scientific production between 2015 and 2018, with a later resumption in 2019.

Hence, the analysis of the Francophone entrepreneurship literature and its evolution over time needs to be better contextualized and problematized. Practices and discourses associated with entrepreneurial phenomena, especially from an economic and social perspective, have been culturally and historically questioned in France (FAYOLLE, 2011). In fact, Marchesnay (2008) points out that French society tends to value, to a greater degree, the large managerial firm, which demonstrates a relative difficulty in abandoning the Fordist model and a disdain for small businesses, considered as less professional. In addition, until the 1990s, France had been dominated by hostile values and institutions to the so-called "entrepreneurial spirit", such as Catholicism, the role of the State in the economy and the importance and status given to stable professional careers, such as public professions and at the executive level. In this scenario, French capitalism is commonly considered an exception, defined as "state capitalism", a peculiar mixture of corporative strategy and public policies, under the influence of a "managerial doxa" (MARCHESNAY, 2011). However, between the end of the 1980s and the end of the 1990s, globalization, technological development and the intensification of transactional relations at the European Union level changed the French society values. This cultural turn increased the legitimacy of entrepreneurs in the business environment, in the political setting and in the media, as well as fostered the increase of academic interest on this subject (MARCHESNAY, 2008).

The studies of Kizaba (2006), Lasch and Yami (2008) demonstrated the emergent character of the Francophone entrepreneurship literature between 1995 and 2005, with a gradual increase on publications in generalist journals and with the rise of specialized journals on the subject. In comparative terms, the period between 2006 and 2019 reveals exactly the institutionalization of this production within the scope of the analyzed publications. In fact, even in a scenario influenced by competition among different research topics, by pressures for the journals internationalization (with the publication of papers in English and with the indexation in scientific bases such as Scopus, Ebsco and Web of Science), there was an increase in the volume of produced and published entrepreneurship papers. This reinforces the legitimacy and potential of the field in the French and Canadian academic context of management. Evidently, the maintenance of such growth and the consolidation of this literature inevitably involves the need for greater theoretical and methodological sophistication, the improvement of literature reviews, as well as the refinement of research methods and techniques, in order to improve the levels of rigor, reliability and validity of this scientific production (FAYOLLE, 2017).

Thus, corroborating with the discussions presented in the studies of Fayolle (2011), Lasch and Yami (2008), Marchesnay (2008), Marchesnay (2011) and Fayolle (2017), our findings suggest the formation of a distinct Francophone field entrepreneurship research. It contributes to the generation of theoretical-empirical evidence about entrepreneurial phenomena from a French-speaking point of view and to the dissemination of this so-called Francophone knowledge on entrepreneurship to a broader, international audience. Such production, a reflection of the increased interest in the theme observed over the past few years, contributes to the formation of a field of studies as multifaceted as the fields from other countries. However, it is important to emphasize that the Francophone entrepreneurship literature presents relevant theoretical and methodological particularities in contrast to those of North American, English, German and Brazilian origin. This conclusion leads us to further our analysis towards the need for identifying these distinctive aspects, including its different research themes. Given this scenario, the Francophone literature was categorized to demonstrate the most explored research topics by researchers in the field (Table 3 ): 
Table 3

Main research topics explored in the Francophone entrepreneurship literature

\begin{tabular}{|c|c|c|c|}
\hline Theme & Articles & Percentage & Accumulated \% \\
\hline Intrapreneurship & 13 & 7,83 & 7,83 \\
\hline Fostering entrepreneurship & 12 & 7,23 & 15,06 \\
\hline Finance & 12 & 7,23 & 22,29 \\
\hline Opportunities & 12 & 7,23 & 29,52 \\
\hline Entrepreneurial education & 10 & 6,02 & 35,54 \\
\hline Female entrepreneurship & 10 & 6,02 & 41,57 \\
\hline Entrepreneurial intention & 10 & 6,02 & 47,59 \\
\hline Entrepreneurial behavior & 9 & 5,42 & 53,01 \\
\hline Entrepreneurship theory and research & 7 & 4,22 & 57,23 \\
\hline Entrepreneurial innovation & 7 & 4,22 & 61,45 \\
\hline Motivation to entrepreneurship & 6 & 3,61 & 65,06 \\
\hline Social capital & 5 & 3,01 & 68,07 \\
\hline Venture creation & 5 & 3,01 & 71,08 \\
\hline Elder entrepreneurship & 5 & 3,01 & 74,10 \\
\hline Social entrepreneurship & 5 & 3,01 & 77,11 \\
\hline Family entrepreneurship & 4 & 2,41 & 79,52 \\
\hline Institutional entrepreneurship & 4 & 2,41 & 81,93 \\
\hline Sectoral entrepreneurship (i.e. luxury) & 4 & 2,41 & 84,34 \\
\hline Collective entrepreneurship & 3 & 1,81 & 86,14 \\
\hline Ethnic entrepreneurship & 3 & 1,81 & 87,95 \\
\hline Rural entrepreneurship & 3 & 1,81 & 89,76 \\
\hline Strategy & 2 & 1,20 & 90,96 \\
\hline Entrepreneurial action & 2 & 1,20 & 92,17 \\
\hline Entrepreneurial learning & 2 & 1,20 & 93,37 \\
\hline Discourse on entrepreneurship & 2 & 1,20 & 94,58 \\
\hline Effectuation & 1 & 0,60 & 95,18 \\
\hline International entrepreneurship & 1 & 0,60 & 95,78 \\
\hline Entrepreneurial teams & 1 & 0,60 & 96,39 \\
\hline Entrepreneurial firms & 1 & 0,60 & 96,99 \\
\hline Entrepreneurial failure & 1 & 0,60 & 97,59 \\
\hline Human resource management & 1 & 0,60 & 98,19 \\
\hline Entrepreneurial orientation & 1 & 0,60 & 98,80 \\
\hline Networks & 1 & 0,60 & 99,40 \\
\hline Risk & 1 & 0,60 & 100,00 \\
\hline Total & 166 & 100,00 & 100,00 \\
\hline
\end{tabular}

Source: Research data.

The findings suggest some important remarks. In particular, the research themes exposed in Table 3 revealed some patterns in terms of investigated topics, demonstrating both the concentration of research interest and themes little explored in the field, which indicates gaps and/or unexplored topics in comparison to the international literature (mostly of English origin). 
In particular, we identified 34 entrepreneurship related topics explored by researchers in the field. Some of these research themes concentrate a significant part of the scientific production on the subject in the analyzed journals. There is a predominance of topics such as: a) intrapreneurship and its variations, such as organizational entrepreneurship and corporate entrepreneurship, and the analysis of its manifestation in the context of small and medium sized private organizations, highlighting processes of innovation, creativity and value creation; b) the promotion of entrepreneurship, including topics such as the role of fostering agencies and the construction of public policies in different regional and national contexts; c) finance, with themes such as venture capital, crowdfunding, among others; and d) the opportunities approach, involving elements such as the creation/identification and exploration of business opportunities, entrepreneurial alert, etc. In addition to these topics, themes such as entrepreneurial education, female entrepreneurship, entrepreneurial intention, entrepreneurial behavior and discussions about entrepreneurship theory and research also attained a relevant volume of scientific production in the analyzed journals.

The set of most studied themes account for $78.03 \%$ of all scientific production about entrepreneurship in French language. It demonstrates the characterization of a list of research topics that establishes a pattern and a broader set of research trends in the field, directing both the generation of knowledge on entrepreneurship in France and Canada and the gathering of research efforts from authors interested in problematizing the nature and logic of entrepreneurial phenomena. When configured under this perspective, such patterns and trends potentially constitutes a Francophone research agenda on entrepreneurship. This allows the exploration of particular theoretical and empirical perspectives, including a range of organizational, sectoral, regional and national contexts. In addition, the identification of this research agenda offers opportunities to publish studies (including Brazilian ones) that investigate entrepreneurial-related themes and disseminate their findings in the aforementioned journals, reinforcing the potential of considering these outlets for the dissemination of entrepreneurship studies.

On the other hand, we found that certain topics have been little explored by researchers. There are gaps to be filled, involving the need for research in topics such as: the relationships between entrepreneurship and family businesses (usually analyzed from the family entrepreneurship perspective); entrepreneurship and innovation; entrepreneurship and strategy; the concept of entrepreneurial orientation; the concept of effectuation; the notion of entrepreneurial process; the relationship between entrepreneurship and networks and/or franchise; and entrepreneurial studies regarding minorities or regional/national specificities, including ethnic, female, racial, rural, sectorial, regional and/or national entrepreneurship. These research themes can contribute to the expansion of existing knowledge on entrepreneurship and to the advancement of the field. Based on this discussion, it becomes necessary to problematize the type of research papers that are published in the Francophone entrepreneurship literature (Table 4):

Table 4

Type of research papers published in the Francophone entrepreneurship literature

\begin{tabular}{lcccc}
\hline \multicolumn{1}{c}{ Type } & $\begin{array}{c}\text { Management } \\
\text { International }\end{array}$ & $\begin{array}{c}\text { Revue Française } \\
\text { de Gestion }\end{array}$ & $\begin{array}{c}\text { Revue } \\
\text { Internationale PME }\end{array}$ & Total \\
\hline Conceptual & 9 & 21 & 10 & 40 \\
Theoretical-empirical & 32 & 39 & 48 & 119 \\
Literature review & 1 & 0 & 6 & 7 \\
Total & 42 & 60 & 64 & 166 \\
\hline
\end{tabular}

Source: Research data.

Although the predominance of theoretical-empirical studies is a relatively predictable result, frequently found in other reviews from different areas of knowledge (ZUPIC and CATER, 2015), some aspects deserve consideration. First, there is a prevalence of theoretical-empirical studies in RIPME (75\% of the total published articles), which may denote a specific editorial profile of this journal in prioritizing and valuing this type of production. On the other hand, RFG is more open to theoretical contributions ( $35 \%$ of the total), a fact that suggests a venue for conceptual discussion on entrepreneurship in this journal. Such papers are relevant for the development of the field, and this RFG fostering helps this endeavor. In addition, 
both RIPME, to a greater degree, and $M I$, to a lesser extent, are venues for the publication of entrepreneurship literature reviews. These reviews explore broader formulations about the construction of the field in the French, Canadian, and even German context. They also present discussions about research topics such as entrepreneurial behavior, entrepreneurial finance, social entrepreneurship, and entrepreneurial orientation. In this sense, the findings provide clues for researchers interested in publishing their studies and results of conceptual and/or theoretical-empirical research in Francophone journals, as they represent opportunities to researchers who seek to optimize and adequate their papers submissions to journals that haves greater adherence to their work.

After the discussion regarding type of research published, it is also necessary to consider the research methods used in the articles (Table 5):

Table 5

Research methods used in the Francophone entrepreneurship literature

\begin{tabular}{lcccc}
\hline \multicolumn{1}{c}{ Method } & MI & RFG & RIPME & Total \\
\hline Theoretical essays & 9 & 21 & 10 & 40 \\
Qualitative & 20 & 28 & 26 & 74 \\
Quantitative & 12 & 11 & 18 & 41 \\
Multimethod & 0 & 0 & 4 & 4 \\
Literature reviews & 1 & 0 & 6 & 7 \\
Total & 42 & 60 & 64 & 166 \\
\hline
\end{tabular}

Source: Research data.

Data demonstrate the predominance of qualitative research ( $44.6 \%$ of the total), a fact that presents an interesting parallel with the observed reality in the field of entrepreneurship research in Brazil (OLIVEIRA JUNIOR, GATTAZ, BERNADES et al., 2018). Another distinguishing feature of the Francophone field, in comparison to the literature developed in other countries, can be seen in the importance attributed to conceptual works ( $28.3 \%$ of the total), a movement that contributes not only to problematizing the area itself, but also to generate contextualized knowledge to the field. These results are different from those observed in other literature reviews, most notably those that problematize scientific production in countries with a greater influence from positivism on the social sciences and applied social sciences (BUSENITZ, PLUMMER, KLOTZ et al., 2014; BLACKBURN and SMALLBONE, 2008; SCHMUDE, WELTER and HEUMANN, 2008).

In general, these qualitative works were developed around interpretive, constructionist, constructivist and structuralist foundations. They have certainly been influenced by a broader tradition of the Francophone academic environment, especially of French origin. Such developments reflect on the quality of discussions, in terms of depth and density, and in the generation of a specific knowledge, more contextualized and circumscribed to the investigated realities, something that differentiates this particular field of studies. On the other hand, these papers, mostly developed from the perspective of case studies or multi-cases, present a certain limitation regarding the range of these contributions in terms of generalizations. Such criticism can also be seen in the reviews of Bizaka (2006), Fayolle (2017), Julien and Raymond (2008), Lasch and Yami (2008) and Marchesnay (2008). Moreover, there are few studies that triangulate research methods, strategies and techniques $(2.4 \%$ of the total), a fact that, at the same time, constitutes a limitation of Francophone production, and an opportunity to carry out studies with greater density and potential to contribute to the field.

Another important aspect of this scope review is the identification of authors considered as references for the Francophone entrepreneurship literature. These researchers are from several countries in the French-speaking community and reveal an interesting academic plurality (Table 6): 
Table 6

Prominent authors in the Francophone entrepreneurship literature

\begin{tabular}{|c|c|}
\hline Author & Qtde \\
\hline Alain Fayolle & 12 \\
\hline Didier Chabaud & 5 \\
\hline Émile-Michel Hernandez & 5 \\
\hline Frank Janssen & 5 \\
\hline Michel Marchesnay & 5 \\
\hline Éric-Alain Zoukoua & 4 \\
\hline Isabelle Calme & 4 \\
\hline Karim Messeghem & 4 \\
\hline Olivier Giacomin & 4 \\
\hline Stéphane Onnée & 4 \\
\hline Camille Carrier & 3 \\
\hline Cécile Fonrouge & 3 \\
\hline Jean-Pierre Boissin & 3 \\
\hline Josée St-Pierre & 3 \\
\hline Maripier Tremblay & 3 \\
\hline Nazik Fadil & 3 \\
\hline Olivier Basso & 3 \\
\hline Véronique Bouchard & 3 \\
\hline Louis Jacques Filion & 2 \\
\hline Louise Cadieux & 2 \\
\hline Lucie Bégin & 2 \\
\hline Pierre-André Julien & 2 \\
\hline Thierry Verstraete & 2 \\
\hline Total & 86 \\
\hline
\end{tabular}

Source: Research data.

We identified 383 authors responsible for publishing the sample of 166 articles, an average of 2.3 authors per paper. This finding suggests a relevant degree of academic collaboration for the production of knowledge on entrepreneurship. Specifically, there is a predominance of authors from France and Canada, mostly based in university chairs in those countries. This demonstrates that the Francophone production is original and that it is generated mostly in research laboratories, in universities, and in research institutions in these countries. Authors based in France (such as Alain Fayolle, Didier Chabaud, Émile-Michel Hernandez and Michel Marchesnay), in Canada (as Camillie Carrier, Maripier Tremblay, Louis Jacques Filion and Pierre-André Julien) and in Belgium (as Frank Janssen), among so many others, produce a relevant part of the Francophone literature in the field, contributing to its development and to the establishment of research topics, research methods, and venues for new studies. However, it is worth mentioning the low presence of Brazilian researchers in the list (only 4 in 383 authors). This suggest a limitation in terms of the internationalization of Brazilian research, but also provide opportunities for the dissemination of studies contextualized to the entrepreneurship reality in Brazil within the scope of these journals. 


\section{CONCLUSION}

This paper aimed to review the Francophone entrepreneurship literature published in French and Canadian journals. To this end, we mapped the articles published in the journals Management International, Revue Française de Gestion and Revue Internationale PME through the scope review method, which allowed the identification and categorization of 166 articles published on the subject in the period between 2006 and 2019.

The findings reveal the constitution of a French-speaking field on entrepreneurship research. This field has particularities that are aligned with other national contexts, such as the conceptual rigor, observed in studies from the United States and England, or the focus on qualitative methodologies, perceived in Brazil. There are, though, some important differences compared to others contexts, such as the value given to conceptual papers and their role in the theoretical development of the field, and the exploration of topics little discussed in other countries, including ethnic, racial, sectorial, contextual, individual, social and gender issues, for example. Thus, a broad and multifaceted framework is formed, with potential to generate solid and sound theoretical and empirical contributions for the field of entrepreneurship research from a global perspective and, evidently, from a Brazilian perspective.

Notably, there are multiple aspects of the production and dissemination of knowledge on entrepreneurship within the scope of French-speaking literature. In comparative terms, the Francophone entrepreneurship literature is in part different from that observed in countries like the United States (with an emphasis on behavioral and processual aspects), England (with an emphasis on organizational aspects), and Germany (with emphasis on innovative and sectorial aspects). Indeed, several authors who sought to problematize the dynamics of entrepreneurship studies in the French and Canadian spheres emphasize the influence of North-American and British schools in the emergence of the Francophone field. However, the evolution observed from the mid-1990s until 2005 was consolidated in the following years, with the authors being concerned with issues such as the theoretical development of the field. Also, French-speaking authors explored and expanded a number of research topics, including the entrepreneurial process and entrepreneurial opportunities, new business venturing, intrapreneurship and innovation, as well as the manifestation of entrepreneurial phenomena in situations and objects that are specifically relevant for the French-speaking context. This fact allowed not only the consolidation of the field in the academic scenario, but also particularize and differentiate the contributions of the field in international terms.

Thus, it seems that the Francophone entrepreneurship literature presents some theoretical and methodological possibilities and alternatives for the development of studies and investigations about entrepreneurial phenomena. This scenario is, at least in part, close to the reality of what is researched, produced and published about entrepreneurship in Brazil. Consequently, we believe that Brazilian authors interested in publishing entrepreneurship papers entrepreneurship can find a space for the dissemination of their articles in French-speaking journals. The Francophone outlet certainly emerges as an alternative and opportunity for the internationalization of the results of investigations carried out in Brazil about this subject and for the international diffusion of the Brazilian field of entrepreneurship research, a venue that is not yet effectively explored in English-language journals.

It is worth noting that this study shows some limitations. First, the set of reviewed journals does not represent the entire scenario of French-speaking entrepreneurship publications, as explained in the methodological section of our paper. However, $R F G, M I$, and RIPME, combined, represent a relevant part of the available means of dissemination for entrepreneurship literature. Future reviews may explore other journals in the field of management, entrepreneurship, and small businesses, expanding the number of analyzed journals or even replicating the list of analyzed journals in other surveys, for comparison purposes. Second, the analyzed period, although relevant, only enables a partial look into the evolution of this scientific production. As indicated, our paper sought to add new evidence to those identified in the studies presented by Bizaka (2006) and by Lasch and Yami (2008). However, we had to conduct this scope review on different journals and time frames, due to the access difficulties also mentioned in the methodology. Despite this limitation, we believe that our review sheds light on the same context of evidence identified by the aforementioned authors, reinforcing and advancing the findings presented in their literature reviews. Future studies could explore a broader time frame and/or add new journals to the sample, in order to access this production in a more comprehensive and wide-ranging way. Third, although our review presents classifications and identifies categories that are consistent with other similar studies, it was not possible to explore other pertinent aspects. We suggest that further Francophone entrepreneurship reviews explore topics such as the main theoretical, ontological and epistemological approaches, the main references and citations/co-citations, the main concepts, and the definitional 
structure of entrepreneurship in the Francophone school. Particularly, we believe that it would be interesting to learn about the similarities and differences between the French-speaking entrepreneurial literature and other schools, such as the North American and the Brazilian. Furthermore, structural aspects such as author networks, regional, national and international institutional relationships, among other topics, could also be objective of future reviews.

Nevertheless, despite these limitations, this review contributes by putting the Francophone research and scientific production on entrepreneurship into perspective, revealing possibilities, alternatives, and theoretical-methodological paths for conducting studies about the entrepreneurial phenomenon. In this sense, there are opportunities for dialogues and exchanges between the entrepreneurship field in Brazil and French-speaking literature, including the exploration, in the Brazilian context, of recurrent topics in the French and Canadian fields, and the publication of Brazilian papers (mainly qualitative ones) in the aforementioned journals. Such an effort could help disseminating theoretical views and Brazilian empirical findings to readers in the Francophone context. Therefore, we conclude that our review contributes to an ongoing process of identifying evidences that support the consolidation, legitimation, and institutionalization of the Francophone field, and to identify, after all, what we are talking about when we talk about entrepreneurship in French. 


\section{REFERENCES}

ALVAREZ, S. A.; BARNEY, J. B. Entrepreneurship and epistemology: the philosophical underpinnings of the study of entrepreneurial opportunities. Academy of Management Annals, v. 4, n. 1, p. 557 583, 2010.

ARKSEY, H.; O'MALLEY, L. Scoping studies: towards a methodological framework. International Journal of Social Research Methodology, v. 8, n. 1, p. 19-32, 2005.

BLACKBURN, R. A.; SMALLBONE, D. Researching small firms and entrepreneurship in the U.K.: developments and distinctiveness. Entrepreneurship Theory and Practice, v. 32, n. 2, p. 267-288, 2008.

BUSENITZ, L. W. et al. Entrepreneurship research in emergence: past trends and future directions. Journal of Management, v. 29, n. 3, p. 285-308, 2003.

BUSENITZ. L. W. et al. Entrepreneurship research (1985-2009) and the emergence of opportunities. Entrepreneurship Theory and Practice, v. 38, n. 5, p. 981-1000, 2014.

CARLSSON, B. et al. The evolving domain of entrepreneurship research. Small Business Economics, v. 41, n. 4, p. 913-930, 2013.

CLARK, C. M.; HARISSON, C. Entrepreneurship: an assimilated multiperspective review. Journal of Small Business \& Management, v. 31, n. 1, p. 43-71, 2019.

FAYOLLE, A. Entrepreneurship and small business research in Frenchspeaking countries: an introduction. Journal of Small Business and Enterprise Development, v. 18, n. 2, p. 1-4, 2011.

FAYOLLE, A. Thinking the future of entrepreneurship research through French lenses. Revue Internationale des Sciences de L'Organisation, v. 2, n. 3, p. 59-72, 2017.

FAYOLLE, A. What we know and what we need to know in the field of entrepreneurship. In: FAYOLLE, A. (Ed.). Handbook of Entrepreneurship Research: what we know and what we need to know. Cheltenham: E. Elgar, 2014. p. 1-12.

FERREIRA, M. P. et al. Entrepreneurship research: a bibliometric study of Enanpads 1997-2008. Revista Brasileira de Estratégia, v. 3, n. 1, p. 31-47, 2010.

FERREIRA, M. P. V.; PINTO, C. F.; MIRANDA, R. M. Três décadas de pesquisa em empreendedorismo: uma revisão dos principais periódicos internacionais de empreendedorismo. Revista Eletrônica de Administração, v. 21, n. 2, p. 406-436, 2015.

FILION, L. J. Empreendedorismo: empreendedores e proprietáriosgerentes de pequenos negócios. Revista de Administração, v. 34, n. 2, p 5-28, 1999.

GARTNER, W. B. Entrepreneurship as organization creation. In: HJORTH, D. (Org.). Handbook on Organisational Entrepreneurship. Cheltenham: E. Elgar, 2012. p. 21-30.

GARTNER, W. B. What are we talking about when we talk about entrepreneurship? Journal of Business Venturing, v. 5, n. 1, p. 15-28, 1990.

GARTNER, W. B.; BRUSH, C. G. Entrepreneurship as organizing: emergence, newness, and transformation. In: GARTNER, W. B.
(Org.). Entrepreneurship as Organizing: selected papers of Willian B. Gartner. Cheltenham: E. Elgar, 2016. p. 291-310.

HARRISON, R.; LEITCH, C. Discipline emergence in entrepreneurship: accumulative fragmentalism or paradigmatic science. Entrepreneurship: Innovation \& Change, v. 5, n. 2, p. 65-83, 1996.

HJORTH, D. Sketching a philosophy of entrepreneurship. In: BAKER, T.; WELTER, F. (Eds.). The Routledge Companion to Entrepreneurship. New York: Routledge, 2015. p. 41-58.

JULIEN, P.-A.; RAYMOND, L. Vingt ans de recherche francophone en PME et entrepreneuriat. Revue Internationale PME, v. 21, n. 2, p. 7-8, 2008.

KIZABA, G. Revues scientifiques et 10 ans de recherche francophone en entrepreneuriat. Innovations, v. 24, n. 2, p. 231-258, 2006.

LASCH, F.; YAMI, S. The nature and focus of entrepreneurship research in France over the last decade: a French touch? Entrepreneurship Theory and Practice, v. 32, n. 2, p. 339-360, 2008.

LEVAC, D.; COLQUHUON, H.; O'BRIEN, K. K. Scoping studies: advancing the methodology. Implementation Science, v. 5, n. 69, p. 1-9, 2010.

LOPES, R. M. A.; LIMA, E. Desafios atuais e para a pesquisa em empreendedorismo. Revista de Administração de Empresas, v. 59, n. 4, p. 284-292, 2019.

MACMILLAN, I. C. The emerging forum of entrepreneurship scholars. Journal of Business Venturing, v. 8, n. 5, p. 377-381, 1993.

MARCHESNAY, M. Trente ans d'entrepreneuriat et PME en France: naissance, connaissance, reconnaissance. Revue Internationale PME, v. 21, n. 2, p. 145-168, 2008.

MARCHESNAY, M. Fifty years of entrepreneurship and SME: a personal view. Journal of Small Business and Enterprise Development, v. 18, n. 2, p. 352-365, 2011.

MCDONALD, S. et al. A review of research methods in entrepreneurship 1985-2013. International Journal of Entrepreneurial Behavior \& Research, v. 21, n. 3, p. 291-315, 2015.

MEYER, M. et al. Origins and emergence of entrepreneurship as a research field. Scientometrics, v. 98, n. 1, p. 473-485, 2014.

NASSIF, V. M. J. et al. Empreendedorismo: área em evolução? Uma revisão dos estudos e artigos publicados entre 2000 e 2008. Revista de Administração e Inovação, v. 7, n. 1, p. 175-192, 2010.

OLIVEIRA JUNIOR, A. B. et al. Pesquisa em empreendedorismo (20002014) nas seis principais revistas brasileiras de administração: lacunas e direcionamentos. Cadernos EBAPE.BR, v. 16, n. 4, p. 610-630, 2018.

RUMRILL, P. D.; FITZGERALD, S. M.; MERCHANT, W. R. Using scoping literature reviews as a means of understanding and interpreting existing literature. Work, v. 35, n. 3, p. 399-404, 2010.

SCHMUDE, J.; WELTER, F.; HEUMANN, S. Entrepreneurship research in Germany. Entrepreneurship Theory and Practice, v. 32, n. 2, p. 289-311, 2008.

SHANE, S.; VENKATARAMAN, S. The promise of entrepreneurship as a field of research. Academy of Management Review, v. 25, n. 1, p. 217-226, 2000. 
SHEPHERD, D. A. et al. What are we explaining? A review and agenda on initiating, performing, and contextualizing Entrepreneurship. Journal of Management, v. 45, n. 1, p. 159-196, 2019.

TEIXEIRA, A. A. C. Mapping the (in)visible college(s) in the field of entrepreneurship. Scientometrics, v. 89, n. 1, p. 1-36, 2011.

TURCAN, R. V.; FRASER, N. M. Multi-disciplinary perspectives on entrepreneurship. In: TURCAN, R. V.; FRASER, N. M. (Eds.). The Palgrave Handbook of Multidisciplinary Perspectives on Entrepreneurship. Cham, Switzerland: Palgrave MacMillan, 2018. p. 3-13.
VALE, G. M. V. Empreendedor: origens, concepções teóricas, dispersão e integração. Revista de Administração Contemporânea, v. 18, n. 6, p. 874-891, 2014.

WIKLUND, J.; WRIGHT, M.; ZAHRA, S. A. Conquering relevance: entrepreneurship research's grand challenge. Entrepreneurship Theory and Practice, v. 43, n. 3, p. 419-436, 2019.

ZUPIC, I.; CATER, T. Bibliometric methods in management and organization. Organizational Research Methods, v. 18, n. 3, p. 429472, 2015.

Alex Fernando Borges

ORCID: https://orcid.org/0000-0001-7269-5196

Doctor em Management at the Federal University of Lavras (UFLA); Adjunct Professor at the Federal University of Uberlândia (UFU), Ituiutaba - MG, Brazil. E-mail: alexborges@ufu.br 